\title{
Kindness: a new kind of rigour for British Geographers
}

Danny Dorling

Abstract

Let's face it, those of us who work in the academic discipline of Geography, largely work on the subject of failure. The failure of political leaders worldwide to avert disastrous climate change. The need to prevent the continuation of the fastest species extinction the world has ever known. The social and personal repercussions of enormous global income, wealth and power inequalities. We describe all this, usually, as if it were just an interesting set of observations. Then we tell students to write an essay about it. If they cogently analyse our collective failure, we give them a high mark. Many of them can then take their university degrees and head out to banking, advertising and management and make the world an even worse place, armed with the knowledge of what they might be critiqued for by those who taught them, but never convinced them. Perhaps if we were kinder to our students when they were at university, were kinder and clearer in what we wrote and taught, more of them would use what they have learnt for good, rather than seeing their degrees as stepping-stones to their allotted place in the social hierarchy.

Keywords: Rigour; Geography; Failure; Apologizing; Emotion; Pride 
British Geography is distinct from US or Canadian Geography. For undergraduates (as we call them in the UK) studying Geography outside of the UK does not come with the association of being more likely to have come from a socially privileged position as a child. In North America and New Zealand, geography is not perceived as especially posh or easy. In the US, it is more of an unknown and hidden discipline that students discover in their 3rd or 4th years. More North American geography 'grads' go into work in city planning or in GIS than to any other job (or so anecdote has it). So, when I speak of 'our' or 'we' in this paper, I must be clear that I mean British University Geographers and their students. In this paper I use a capital G for Geography whenever I am talking about British Geography. I am writing for people like me, a British Geographer, and our collective failure.

It's not a weakness to admit failure, it is a strength. However, Geographers still have to contend with the peculiarly masculine legacy of exploration, colonial appropriation, and the original military function of much mapping. Today we may critique the ethos of exploring 'virgin lands', 'empire 2.0' thinking, and explain the derivation of the words 'Ordnance Survey', but often we carry on being like our forefathers (they were almost all men) in other ways. For instance, we tend to still be remarkably selfassured. In the 1949 Western 'She wore a yellow ribbon', John Wayne gave a young man a piece of advice: "Never apologise, mister, it's a sign of weakness" (Wayne, 1949). The clip of him playing the cowboy, astride his horse and uttering these words of supposed great wisdom to a younger man epitomises this macho attitude of arrogance and brittleness that continues to pervade much of western society, academia included, and especially Geography. Geographers are 'tough', they climb mountains, they are still explorers, they are more robust, more rigorous and more 'out there' than other academics, and thus that legacy of toughness of attitude still endures. It does so today, long after we began to deconstruct our recent past. 
Geography in the UK emerged as a discipline at a time of emotional repression and the famous British 'stiff upper lip', where admitting your feelings was - as Wayne would say years later - 'a sign of weakness.' In this article I discuss emotion, failure, and the role of kindness within contemporary British Geography. At times I may appear to be disheartened; but being trained as a Geographer I have learnt to persevere, to hide my feelings in meetings, not to say what nonsense so much of what we do still is; and not to come clean about what we could do if we cared more and held back a little less. Other British geographers have started to speak out, but so far not many. Kye Askins, in describing a research project that she felt was going wrong, is unusual: "I realised that this emotional drain had bled into my academic role, also demeaning my sense of professional value, and the idea of a Research Council grant and some 'big papers' had become seductive. The more I reflected, the more upset I was with myself: I felt that l'd let everyone down..." (Atkins and Blazek, 2017).

Geography became acceptable as a British university subject in 1899, when The Times announced that a new school of Geography was to be established in Oxford (England). This was to ensure that there would be no future excuses of ignorance for the establishment's efficient 'conduct of the [British] Empire's affairs'. Geography was created as a discipline for 'Men who think of entering on a political or military career, or who intend in one capacity or another to take service in some part of the Empire beyond the seas, or who look forward to having dealings with foreign countries...' (The Times, 1899). Geography was a discipline for young men drawn from the upper orders of society, those destined to rule over the lower orders. From the out-set, a token nod to widening participation was made. The Times article of 1899 ends: 'There will be at least one scholarship of $£ 60$, attached to the school. There is every reason to hope that complete success will attend this new departure.'

\section{A little history}

But what is success, and what is failure? Geography departments began to proliferate not only across the UK, but around the Empire; including (but only rarely) in those former colonies that are today the USA. The Department of Geography in Liverpool was founded in 1917 . Today on its website, its successor, the Department 
of Geography and Planning, boasts that: 'Liverpool is home to the oldest Black African community in the UK.' (University of Liverpool, 2019). Yet, nowhere does it mention that Liverpool was once one of the three key points on the triangular slavetrade. This is just one of many examples of attempts to deconstruct and then reconstruct our past; while at the very same time echoes of toughness and obscuration endure. At the centenary celebrations 'Vice-Chancellor Professor Janet Beer said: "Here at the University of Liverpool we have a very proud history of leading the way in Geography..." (University of Liverpool, 2017). ${ }^{1}$ Leadership is still seen as so important in both Geography Departments and Universities as a whole. Whenever I hear the word leadership, I am reminded of the pith helmeted geographer leading his men and porters through the jungle.

Although Liverpool was one of the key points of the triangular slave-trade, its University Geographers were educated long after that trade had ended. Today we like to pretend that all that we do is for the good, all the bad being in our past. However, no one has ever audited the undergraduate output of the discipline. Instead we whisper to each other, isn't it amazing that so many of the banks took on so many of our students to work in London before the 2008 crash. Out loud we say that "Geography has a critical role to play as we face global challenges that span the social, economic and environmental". In secret we comment on how remarkable it is that so many of us who did not stay in academia went on to work in the military (including in spying), for hedge funds, as financial consultants, and as teachers, some of which can be seen as fields where a sense of superiority and of command over others are key assets.

Pride and success have a tendency to come before a fall. In the 1970s, as the British Empire fell and its colonies won back their freedom, the fate of Geography as a frontier imperial discipline hung in the balance. A subject that trained posh young men to wield control over foreign places could easily have been consigned to the dustbin of history. In the USA, and elsewhere around the world, many departments were closed or merged into something else. In Britain the new 1960s universities of Warwick, York and Strathclyde decided not to include Geography in their remit. However, Geography survived. Climate catastrophe, growing global inequality, and the rising popularity of interdisciplinarity has helped; but Geography in the UK has become a soft option for those who come from upper middle class families where 
increasingly you are expected to go to university, especially for those who were privileged (and so often have high GCSE marks) but are not actually that good at maths, or writing, or reading, or science, or imagination. And so, a century on from the founding of departments such as Oxford and Liverpool, it may finally be time (and kind) to talk about failure - despite the emotional costs involved.

At the start of the 1970s in England, boys from the top public schools ${ }^{2}$ were not always expected to go to University. Some went directly into the military to be trained as officers, while others went directly into the City of London to start work at age eighteen. However, by the end of the 1970s parents who sent their children to such schools increasingly expected them to gain a place at university, especially a place at a prestigious university. Geography's association with the English upper classes and upper middle classes can be traced back to that time. Knowing this helps you understand why so many went into finance (they had family connections) and why British Geography departments so often are found to have some of the narrowest and poshest social profiles when the backgrounds of students across an entire University in England are assessed. All this is changing, but if we don't admit to this legacy, we will not easily understand ourselves. Geography in Britain, from the time of my childhood onwards, began to admit an unusually high number of students from more privileged backgrounds, often from schools that were not especially kind; and often those who arrived were not seen to have succeeded by arriving at University because almost every child at their school went on to University. They were more and more usually seen by their peers as not having done that well and hence having had to apply to study Geography.

Talking about failure may be a sign of hope. In the summer of 2018, Tom Disney, Thom Davies and Elly Harrowell of the Universities of Northumbria, Nottingham, and Coventry organised a session at the Royal Geographical Society annual conference in Cardiff, on 'failure' within human geography (see Harrowell et al. 2018). It was titled 'Reclaiming failure in geography: academic honesty in a neoliberal world'. This paper has been written in response to that call, and because I wanted to say something both about our history and reality, and about being kind and compassionate in Geography. I want to suggest that we should think more about kindness. 


\section{Kindness in Geography}

When asking a question at an academic conference, when posting on Twitter, when commenting on a piece of written work by a student, or writing a book review and making a particular point: 'is your intention to correct or connect?' (Selle, 2017). Refusing to accept that failure is normal and is all around us is not kind. The discipline of the stiff upper lip badly needs more kindness shown both to others (and oneself). The need to face our failures applies to the subject as a whole, and to how Geographers choose to conduct their own work of research, teaching and administration.

I am currently the Director of Graduate Studies in the School of Geography and the Environment at the University of Oxford. This means that I have a duty of care for roughly $150 \mathrm{PhD}$ students. I get to see all the termly comments of their supervisors, the internal reviews of their work by other academics, their requests to suspend their studies due to illness, many of their applications for permission to do something not normally permitted by a particular rule, their applications for funding, for exceptional leave to delay, and all their final examination reports; including all those that say that what they have done is not good enough.

Some academics can be very brusque. It is not a great problem when they generally like the work they are commenting on; but where they don't agree with it - and especially when a student's work is actually weak - then kindness is essential and being brusque and to the point often means being brutal. As Geographers we must turn our critical gaze on our own actions and interventions, as well as assessing others. We must recognise we have a legacy of 'the strong man' despite so many younger academics now being women. Hardly any older academics were women in Geography in the past, as books on 'Great Geographers' made clear. If we geographers can better deal with that legacy, and with our past properly, we could be so much better, so much kinder in the future. Geography could become the discipline of the future, the subject that studies the impending world in an involved and helpful way - not a distant, arrogant or all-knowing way. We could use our reputation as a weak science to our advantage, taking people with us rather than lecturing down to them. We know what we expect the climate to be like and how we could prevent it 
becoming that inhuman, we could talk more of what we hope society will develop towards, we could talk far more about compassion and empathy. Few people do not hope for a kinder future.

Kindness is a kind of rigour. It is hard to be kind; much harder to be kind than to always (in your own mind) be right. If Geography aimed to be "the kind discipline", it would help to break a wider problem that academia has in spades, and the social sciences have by the bucket load: academic arrogance. As was tweeted in 2014 by an anonymous academic (who at the time of writing had over 311,000 followers): 'We're all smart. Distinguish yourself by being kind.' (Academics Say, 2014). But we are also all stupid, which is an even better reason to be kind.

Don't be nasty, not least because it is so easy to be wrong - especially if you think you are ever so clever (and I really do not mean to be unkind here). In several books I have written at length on how richer and more powerful people often: 'assume they must be 'phenomenally bright', when in fact any ability they may have to pass examinations is not unusual given their social advantages' (most recently in Dorling, 2018). Kindness is much more than the geography of care. To be kind you have to try to be less sure of your superiority, your great knowledge and your power to discern whether others' work is very good or very bad. And you have to understand why we are also so equal, which includes all having the ability to very often be stupid in what we do. We must talk less of brilliant minds and exceptional students. Apart from anything else it reveals how unaware we are of what is now known about the human mind. Few minds are brilliant, but with dogged determination and a lot of help (and luck) you can train your mind to work in unusual ways; including to be less arrogant and more kind.

Kindness is a vital yet unseen aspect of academic work in general, and Geography in particular. It is something that all geographers rely upon during fieldwork, data collection, in gaining access to archives, to data and to interviewees. Without kindness, we are all surely destined to fail. However, as Professor Marie Price once explained: 'geographers seem reluctant to admit how much we rely on the kindness of strangers' (Price, 2001). Marie went on to explain that Geographers, like many academics, are also prone to overestimate their importance and insight. She explained when talking about writing up fieldwork: 'In conversations with other 
academics about this essay, the term "war stories" was tossed around, usually in the context of, "So you're going to tell your war stories!" The more I encountered the phrase, the more it bothered me. ... To be honest, what I actually write will be of little interest to the immigrants themselves.' Indeed, what she wrote was indeed of little interest to the immigrants she was studying, because they knew it already. Often Geographers are of the privileged few, writing almost exclusively for each other, about what they have discovered concerning other, almost always very different, peoples' lives.

\section{The Geography of privilege}

It is not our fault if we are born into privilege, but we should at least first acknowledge, then apologise if at any time we have ever pretended that any of this is fair, and that we are where we are due to merit, not due to what actually happened to us and to luck. As I have alluded to already, British Geography departments tend to be made up of a higher than average proportion of students from richer homes; higher than is found in almost any other discipline (Bennett, 2018).

It is increasingly from that set of more-affluent-than-average students that current and future British Geography academics are being drawn, especially as they now need their parents to fund their master's degrees and occasionally even their $\mathrm{PhD}$, before they can even start to contend. Older British academics grew up at a time when Britain was more equal by social class, when educational opportunities, albeit mostly for men, were far less prescribed; when a parent-funded master's degree was not a barrier because almost no academic had a master's degree; where almost all PhD students were Research Council funded; and when the wealth and position of your parents was not sure a great influence on your future.

Young British academics are much more the product of an increasingly socially divided society where the large majority come from the better-off side of the far-wider tracks. My own University in Oxford (England) now publishes annual statistics on the social background of undergraduates by academic discipline and this revealed what any human Geographer with GIS skills and access to the postcodes of all the undergraduates accepted to their university has long known, but has only ever quietly 
mentioned to a few colleagues. In Britain, Geography errs toward accepting more of the affluent, not least because so many more of them apply to study it. In Britain it is the subject that the future king (William) took at St Andrews. It is the subject that the founder of the 2018 British Brexit Party studied at Christ Church, Oxford. It was the subject studied by the recently departed Prime Minister and leader of the Conservative party, Theresa May. It is what the leader of the Labour Party (from 2015 though to today) was asked to teach in Jamaica, when sent there as an eighteen-year-old overseas volunteer, because Geography was, and is, seen as 'easy', not something you needed to be qualified in to teach.

Never apologising means never admitting to any failure, no matter how slight. But we all fail, often repeatedly, and we belong to institutions, countries, even entire academic disciplines which behind their apparent facade of greatness, usually conceal a long liturgy of failure. Our universities fail to control their elitism; we may suggest that our countries (by which we mean our fellow citizens) so often fail us in what we wish they could be; our academic disciplines often don't appear quite up to the job of being such shining examples of the truth and the light that they are presented as being - in which the very best work is of such international greatness that just one star will not do to describe it and it needs four stars to illuminate its magnificence. ${ }^{3}$

I am and have been remarkably privileged, lucky and at key times have been shown great kindness. My failures have been substantial, and that includes just the few I am willing to admit to in public. It is easy to list where I have been told that I have failed, especially when I have felt slighted, or wronged. After all, that list might make me look good in an odd sort of a way (given the job title I have now). But it is much harder to admit to my many failings as regards how I have treated other people even just the failings I know about. Especially those failings I continue to repeat, and for which I have never apologised or even properly recognized.

For what was initially ${ }^{4}$ an 'intervention' such as this one, the journal that this brief article is printed in states: 'We encourage submissions with emotions at their 'heart', that extend scholarly ways of knowing and being', so please bear with me while I unburden myself of a few strong and intuitive feelings as regards to admitting failure, especially as regards my failing of others. 
I regularly fail people. It is a significant part of my job. I spend a large part of many days failing people in various ways. Most of the replies I send to email requests are about me not being available to give that talk, or make that meeting, and I am often slothful in not replying more helpfully than I do. I am very lucky to get so much attention, but instead of recognizing my good luck I regularly moan about the emails I receive and pontificate over how on earth am I to deal with them. Incidentally, if you happen to believe in the dominant narrative, that you are reading this because you have worked hard and fulfilled your inner academic potential, or that I am where I am today because I worked so very hard, it is worth reading a little more on luck and chance. Especially readable and very telling is 'Success and Luck: Good Fortune and the Myth of Meritocracy' (Frank, 2016).

I am complicit in some of the greatest failures of the lives of others. For instance, by not complaining more, I have appeared to sanction what are clearly discriminatory practices involving admitting students to all the universities I have ever worked in (accepting high A level grades as meaningful). ${ }^{5}$ I have interviewed children at the University of Bristol who were in want of a place to study Geography and, because I was told I should do so, I turned the majority away. We interviewed five or six times as many as we had places for. I should have said no when I was asked, but my excuse was that I was young and inexperienced. In reality I thought that I had the ability to spot the potential in others - how wrong I was! I know that now because I have since met several successful academic researchers who told me I turned them down when they were interviewed one-to-one in the 1990s in Bristol (in my defense, I did a lot of interviews).

You might say 'I was only following orders', but in hindsight what a stupid thing that was for me to have agreed to take part in. I doubt the School of Geographical Sciences at Bristol does this anymore, interviewing so many for so few places. And I do apologise to anyone reading this who remembers being interviewed in the 1990s by a very young Danny Dorling, and then not being offered a place. Who was I to know which students might do well or poorly? I had no way of knowing, just the confidence that comes from arrogance and the naïve belief that my older colleagues knew what they were doing, and so I should copy them. ${ }^{6}$ However, it is not just interviews that are suspect when it comes to choosing who should study at any university. Choosing based on University application forms, GCSE and A level 
grades is just as suspect. In more equitable countries, students are not sorted in such silly ways geographically. Instead the majority simply attend their local university.

\section{Realising about potential}

Nobody can call themselves a knowledgeable social scientist and believe that the grades a child achieves at age 15/16 and 17/18 are anything 'much more than a signpost to your street, school, and socialisation' (Dorling et al., 2001). I may have written those words eighteen years ago, having moved to the University of Leeds, and I have published much evidence of the truth of this claim since then; but I have failed to act on it. I have failed to suggest an alternative to how we currently award places at British universities. All I have done is ensure that I am no longer one of those people who has to choose. I have failed to change the status quo.

Like most of us who work in universities, I have only questioned the robustness of student admission and academic job interviews in private. You know the way you do, when you say to a friend (in great confidence): "can you believe that they appointed him?!". No self-respecting social scientist who has an inkling about what implicit bias means can believe that interviews do much more than ensure that when choosing between otherwise almost identically qualified candidates, we increase the chances of our collectively picking the one who we find least challenging - to put it as politely as possible. There are better and more careful ways of selecting who gets life's prizes, which include ensuring that there are more prizes and no one prize is excessive in size, but I have never found the time to argue strongly for those other ways, other than in writing in the abstract about such things. If you are interested in what that better way is, then it helps to know that England is not in a good position. Starting off with a colonial university system, mostly built up at the time of Empire, designed to select children with particular traits and take them away from their home towns - is an odd system to have when you no longer have an Empire to run.

Once students arrive at the university, I fail them. I do this most often by continuing to support the idea that a series of numerical marks can in any way accurately reflect how good their work is. I can still remember being given a third-class mark by Peter Taylor at the age of eighteen (we often remember our failures well). Unusually for a 
Geographer then working at the University of Newcastle upon Tyne, Peter encouraged first-year students to see him if they did badly, so I did. He explained to me what I needed to do to improve my grade, and so, from then on, I did. But, had he not done that, and had I not mustered up the courage to see him, I would have never been taught the rules of inter-subjectivity or have known from an early age how utterly arbitrary the mark on an essay can be; and how you can help the University marker give you a higher mark, by writing what they enjoy reading rather than what you necessarily believe. I am eternally grateful to Peter for being so kind and explaining this.

Peter pointed out to me where I had written things that were wrong and why they were wrong. He explained where he and I disagreed, and where I might have been right, but as he was the one doing the marking it might make more sense to go along with the story he believed. He showed me where and how it was possible to challenge the academic who is marking your work in a way that might mean you relieve their boredom in having to mark so many similar essays by brightening up their day with what, for them, was a new thought. Between the lines of what he said he demonstrated to me how little time an academic has to actually read student essays. It only took him an hour to explain to me what I needed to do to receive first class marks rather than third class ones. But had he not done that; I would never have known.

One of the referees of this paper suggested that I could have been kinder to our own Geography students when I suggested that they are often not good at maths, writing or imagination. That referee argued that as educators it is our job to engage them in learning these skills, in a kind and encouraging way. I would agree. That is what Peter did for me. I received one to one tutoring for maybe only three hours, in total, in the three years I spent as an undergraduate, but that was all that was needed because it was directed.

For instance, Stan Openshaw, the (then) lecturer (who went on to supervise me as a PhD student) taught me how to use the university mainframe in one of those three hours. However, as educators we are left in Britain with the very tricky job of explaining to students who may have been awarded an $A, A^{*}$, or 9 or 8 at Maths or English at GCSE that this does not mean that they are brilliant at these subjects and 
will be able to think imaginatively about data or write engagingly about a topic. It usually just means they were taught how to jump through the hoops of the British GCSE marking system well; a system that has taught them that marks matter above all else.

Today in Britain our students have grown up immersed in an education system that is now one of the most inequitable to be found anywhere in the world. This is in terms of so much more being spent on the more elite of private school children as compared to the funding for state education and the huge and growing divide even within English state schooling. This does not mean that those who have had more money spent on their education have realised their potential. We all have enormous potential. It means that they have been better taught how to get high marks.

Students now take their marks much more seriously than I and most others did when we were young. Perhaps more is at stake, and I have often failed to pass on Peter's advice. Students today are so used to receiving marks, that they accept the two-digit numbers as a kind of gospel truth. Universities encourage this, when they state that 'academic judgment' cannot be questioned, and that only the technicalities around marking can be disputed - but not the magic numbers themselves. We have made ourselves into a new priesthood where we, and only we, can talk to god and ascribe the magic numbers. However, students, especially when they are buying a degree, do sometimes try to question the apparently handed down from on high 'indisputable word of God' that is their marks.

The vagaries of marking escalate as you age. What is or is not of "PhD quality"? Who of eleven candidates should receive one of the two research fellowships worth hundreds of thousands of pounds? At one point in my career, while working in Sheffield, I watched, and took part, as eleven judges marked the work of eleven such candidates (I was a judge by that point in time, a few years earlier I had been a candidate). I was surprised at first to see that the marks given formed a perfect Latin Square - an arrangement where high support for any candidate did not appear more than once in any column. All the judges (the rows) ranked top a different candidate (the columns) as compared to every other judge! There was not even much agreement about second and third preferences. 
In hindsight, finding a Latin Square of marks for people doing well in their mid-thirties and taking part in a funding competition for a personal university fellowship is hardly surprising. Almost all the candidates who had made the final short-list were exactly the same age (a few months below the age cut-off for applying for the prestigious fellowship); almost all had equally impressive records to each other; almost all were planning to concentrate on very different topics; all the judges saw one topic or person as much more important than the others - and not even a single pair of judges agreed on one candidate being the strongest. Upon seeing the Latin square emerge, the most devious two of us quickly traded support to ensure our two favoured candidates were funded. You may well be where you are now because your unknown past sponsors were similarly Machiavellian. Or you may not have won that prize because they were not so devious. I have often thought that there must be better ways of distributing research funds, through cooperation rather than arbitrary competition. But I have failed to act on that too. It is easier to simply continue to tacitly support the status quo.

\section{Emotion, Progression and Promotion}

Emotional geographers (as some have labelled themselves) examine the bonds established between people and things, such as between people and money, or between status and individuals. They talk of 'affect' meaning that which 'articulates life and the situations in which it is lived as a series of events which exist in process, being made and remade over time by the performances that bodies enact and get caught up in' (O'Grady, 2018). In the late 1990s I sat in the Highbury Vaults pub in Bristol (England) listening to a group of young male postgraduate students talk about what they were learning on their master's course (the young women must have been in a different pub). In subsequent years I watched these young men take part in a series of events, that can now be seen to have existed as part of a larger process which was being made and remade over time whereby they were caught up in performances that resulted in the majority of those young students around that pub table securing academic posts and later promotion. Recently, I heard how one of this group (now a full professor elsewhere in England) had treated a postgraduate student with the same disregard that he had complained of receiving from his own 
supervisor over a generation ago in that pub in the 1990s (his own supervisor had been too busy to read their PhD student's draft work). I should have said something but didn't - as it would have been embarrassing.

I was reminded of all this when reading the first page of an early paper concerning affect and emotion. That paper ended by suggesting that a theory of affect and emotion could include the political practice 'of affective intervention enacted through generosity, hospitality, trust, friendship, solidarity, respect or responsibility' (Anderson and Harrison, 2006). I have failed to ask my colleagues who have worked so closely with each other as their careers have progressed what, other than supporting each other in future, they expected to achieve? But perhaps solidarity is enough? We cannot have greater cooperation that is meaningful without generosity, hospitality, trust, friendship, respect or responsibility. Unfortunately, if we respect our own friends and those very like us too much, and outsiders less so, we quickly create a clique and are in danger of collectively spiralling downwards while telling each other how great we all are. We can cite each other and in the very small world of Geography those citations may look impressive in number. In other academic subjects you tend not to personally know the people citing your work because other subjects are global (rather than being mostly British and, to a lesser extent, American).

One of my favourite personal failings, and one that most hurt me at the time (because I had too much pride), was being initially excluded from the 2014 Research Excellence Framework (REF) at the University of Sheffield. My work was not deemed of good enough quality. I was simply 'not excellent enough'. I was excluded until the point that I was offered a job at another university. The then Vice Chancellor of Sheffield intervened, perhaps because it was the University he had attended as a young man (and worked in as a middle-aged man) that was making the offer. I was suddenly included again in the REF at Sheffield. Suddenly I was again 'Excellent' rather than a failure. Had I not been offered the new job, I might have believed the judgement of my peers. We are just as liable to take to heart being told we are terrible (when that is not true) as being told with generosity and solidarity that we are wonderful (when that also is not true).

If you survive for a long time in academia, you are increasingly invited to write for journals, rather than having to speculatively submit papers. I was invited to write this 
piece although it was later quite thoroughly refereed, not least because its contents are unusual (the more candid first draft shocked some earlier readers; this final one is a little watered down). I agreed to write this piece because I had just been turned down by a Geography journal the week before, having submitted a requested paper to them (a request does not guarantee publication). The editor of that journal told me that what I had offered them was too one-sided to print. I asked, but they would not tell me, what the other side might have been. Instead they sent me a list of objections that the single referee had. Being kind I have not named the journal, but I would be happy to publish the very negative review I received if anyone would print it (alongside the article it refers to, which has not been published as a result).

Of course, listing just some of my failures, is similar to listing my successes and saying: "haven't I done well given what fools these folks have been about me". That, of course, would be neither true or kind. What is far harder, yet more useful, is to have a think about when I (or you) have been an idiot. The word idiot is derived from the Greek iठıı́itns meaning a private person, someone who does not think of others enough, if at all, someone who is not kind.

\section{Reflection}

What have I done that has made someone else feel small? What clever quip have I ever written in a referee's report that has made the reader cry? When did I not have the time to write a few nice things, before I said that there was a major problem with a paper I was reviewing? What difficult question have I asked of another at a job interview that has made their stomach turn unnecessarily as they squirm in their seat, thinking that they are about to lose the chance of a permanent post for life just because the professor in front of them (me) is trying to impress his colleagues with his wit? What forms of collective bullying have I taken part in? Usually implicitly by not questioning out-loud research excellence frameworks, teaching assessment exercises, and as I mentioned above, helping support the pretence that the marks we hand out to students for their essays are not - above all else - partly random. Depending on the subjectivity involved and the nature of the work being assessed the marks we award single pieces of work can be more random than they are precise, at least in the second digit of the two-digit number each student receives for 
each single piece of work, but with a slight bias towards higher marks for slightly better material. It may be a shock to read this; but then you should also know that as long as there are no systematic biases and your final degree result relies on the averaging of many such marks, the apparent injustice of this process is lessened.

An analogy to admitting the fallibility of academic marking might help. Imagine someone who is religious reading a confession in a paper (such as this) that a particular priest does not believe that offering forgiveness is all that accurate; but it is better to offer it than to say "I am beginning to doubt I am passing on the blessing of the divine". I would much prefer we gave marks of 5, 6, 7 and 8 , rather than 55,65 , 75 and (very occasionally) 85. I think it would be more honest. Incidentally, I don't think I have ever had to give a mark below 50 in my life. I have been lucky with what was normal where I have worked, and I hate failing people, especially those much younger than me!

The older you get, the longer should be the list of your own failures that you are able to recognise. Unless, of course, you even fail to recognise just a subset of your own mistakes.

So where could thinking more often about failure and kindness take us? It is worth being positive and not beating yourself up too much. You are either nearer the side of the progressives, or you are nearer the side of the reactionary failures, and you have a choice over which of these two sides to take and where to position yourself in between them. If you work, like me, as an English (I'm not very British) Geographer, you can either try to celebrate the work of much of the past century - or you can explain it as a key legacy of the British Empire. You could more honestly paint your academic discipline as an unsurprising development in a country that invaded more of the current members of the United Nations than any state on earth ever did before and is likely to ever do again. As former British Prime Minster Gordon Brown put it, of the present 193 members of the UN, Britain conquered or invaded at least 90 per cent, 171, of them (Brown, 2017). There is a reason why Geography is not taught as enthusiastically or as often anywhere else in the world outside of the British Isles.

Geography may produce some amazing teachers, environmentalists, and even bus drivers (the youngest female bus driver in England secured her license only weeks after she secured her Geography degree in 2019) but it is, and remains, the favourite 
subject of those who create hostile environments for immigrants, who create political parties that border on the fascist, of war-mongers, bankers and imperialists. Admit your mistakes, the more the better, but make sure you are not among the worst of all offenders.

Geography as an academic discipline in Britain has itself been involved closely at the core of a series of important failures, stumbling from the discipline created to more efficiently and academically run an empire, through to not recognising that the glaciers were shrinking, and teaching of the ice age to come (for decades), through to all the oscillations from (what Doreen Massey called) the penis-envy of social physics to (what I think of as) the narcissism of cultural theory and theories of knowledge. You may think I am not being kind, but what is kinder - to keep quiet or to suggest that a little more reflection and a little less celebration may be warranted?

\section{Conclusion}

British Geography has 'been exposed as a handmaiden of empire, providing its experts, maps and institutions' (Legg, 2017). Calls have been made from within the discipline to admit to its history of failure and to next adopt 'a decolonial agenda that steps away from a fixation with epistemology [theories of knowledge], and towards praxis [doing] that both reveals and seeks to address how forms of violence and 'microaggressions' experienced by Indigenous and racialised groups within the academy and in everyday life are both normalised and officially sanctioned by institutional arrangements' (Esson et al., 2017). Light can be seen at the end of a very long tunnel because 'the discipline is now inserted into ongoing dynamics of coloniality, but is also well placed to respond to the call to decolonise knowledge. (Noxolo, 2017). There is much that is not failure. However, Geography in the UK remains the discipline that failed to be as kind as it could have been and as good as it could be. It could well succeed in the future, but we must better understand its failures if we are to look back when we are very old and say - that was worthwhile.

Today, Geography is only taught in a tiny minority of universities around the world and lacks global reach despite its colonial origins. The British excelling at Geography is similar to how they excel at Tiddlywinks, and the "sitting down" sports behind 
'Team GB's' Olympics success (rowing, shooting and cycling). Let's admit that we work in the subject born out of the failure of the end of an enormous empire which lacked a compassionate empathetic core, and see whether, out of that understanding, what such an admission brings us; and whether we cannot do a little better in future.

Let us talk about the "in-take", and the potential failure we may make in the future if we do not ask why our in-take in Britain is so odd as compared to the large majority of other academic disciplines. On March 23rd 2018, almost 120 years after celebrating its founding, The Times newspaper ran three stories within a single issue on my own School of Geography at Oxford after internal analysis of student data had revealed that, of all the larger teaching departments at this university, Geography's intake was disproportionately made of up students from the posher backgrounds. How did we get to that place of league table failure? It has been true of every Geography department I have ever worked in, and there is not a little irony in the fact that it has been the work of Geographers, with postcodes, that revealed British Geography's own posh-kid poll position.

Let's turn things around a little, and see the advantage of being an academic subject disproportionally taken by young people who are expected to attend university given their social background, but who do not yet necessarily have a special aptitude or interest (these are called "all-rounders" in England). We should also admit that thankfully more students are now coming to study Geography because they see the world as an interconnected whole, so what has occurred in recent decades may be an aberration. But it is a very recent aberration. Former Prime Minster Theresa May (Geography, St Hugh's, Oxford, 1974-1977) and the future King of England, Prince William, (Geography, St Andrews, 2001-2005) exemplify the range of the typical previous 'type': Theresa May, a poorer but still socially elevated vicar's daughter through to Prince William, the male heir to the throne. And as remarked upon above, even the current leader of her majesty's opposition (Jeremy Corbyn) worked as a Geography teacher when he was eighteen years old (Craig, 2016). While Catherine Blaiklock, who read Geography at Christ Church Oxford in the early 1980s, was leader and founder of the UK 'Brexit Party' until she had to resign in March 2019 for 'unfortunate' things she had recently said about Muslims which were revealed by the press (Walker, 2019). 
Geography could do so much better in who it takes in, what it produces, and where it is going. It took a geographer to point out to his academic colleagues that: "While aviation is currently only a small part of the global emissions profile, it is the only sector that is rapidly expanding with little international or national action to curb growth. Many frequent-flyer academics could simply gear down and only attend "must-go" conferences. Conference organisers, as well as grant-awarding bodies, can play a key role by offering discounts to those who do not fly." (Chatterton, 2019). His suggestion: free conference entry for anyone who does not fly! What else could we do better? Should there be fewer conferences?

Perhaps the most famous Geographer in the world today, the person who best explains climate change to the widest of all audiences and who highlights how we are all socially connected, had these words to say recently: "For way too long the politicians and people in power have got away with not doing anything at all to fight the climate crisis and ecological crisis. But we will make sure that they will not get away with it any longer" (Greta Thunberg quoted in Jarvis, 2019). I should add that she may not know that she is a Geographer! However, she knows what matters most and is remarkably accurate in her concerns and advice (Dorling, 2020).

The greatest change in the world and to the very small world of British Geography in my lifetime has been to see more and more younger women demand inclusion. The old macho discipline will appear to be so different in the future (as will the wider world); but for British Geographers we will live for some decades to come with the legacy of who we are and the incredibly divided school system and society from which we have mostly emerged. The Geographers who taught me, almost entirely men, and now almost all retired, grew up in a far more economically equitable country than those who are younger than me did. We rarely, if ever, reflect on the positionality of a discipline as a whole. Today's associate professors were yesterday's students. In Britain this means young people drawn mostly from an unusually narrow and affluent social segment of society, although a far less male dominated group than in the past.

What is wonderful about all of geography's failure is that there is nothing intimidating about answering "I am a Geographer" when asked what you do. Not automatically being superior to others helps with being kind. British Geography departments also 
increasingly include people whose first degrees, and occasionally their PhD's were in Physics or Economics, Geology or Politics - but they too can take on the mantle of 'Geographer'. Because of the legacy of failure associated with the subject, when asked what you do and replying, 'I am a Geographer', does not immediately put the other person at a social disadvantage by the cachet that comes with the role. This really is worth celebrating. It is good to know you are weak, not superior. But try, as hard as you can, not to be nasty. Turning the lens back on yourself, on ourselves, and arguing for geography to become the kind discipline of the future is not a sign of weakness. We should always apologise; it shows we are still learning and that we know we still have so much to learn. The planet is now quickly warming; its people are hugely divided; Geography should be the academic subject of the kinder future to come. What was once the core subject of imperial domination can and should be turned inside-out and upside-down.

\section{REFERENCES}

Academics Say (2014) Tweet by "Shit Academics Say" $12.38 \mathrm{pm}$ on $20^{\text {th }}$ August:

https://twitter.com/AcademicsSay/status/502057155437281280

Anderson, B. and Harrison, P. (2006) Questioning affect and emotion, Area, 38, 3, 333-335. https://rgs-ibg.onlinelibrary.wiley.com/doi/abs/10.1111/j.1475-4762.2006.00699.x

Askins, K, and Blazek M. (2017) Feeling our way: academia, emotions and a politics of care, Social and Cultural Geography, 18, 8, 1086-1105.

Bennett, R. (2018) Geography finds its place among elite, The Times, 23 May, https://www.thetimes.co.uk/article/geography-is-degree-for-the-well-off-b0gbc56zz

Brown, G. (2017) My Life, Our Times, London: Bodley Head, p. 27.

Chatterton, P. (2019) The climate emergency and the new civic role for the university, The Ties Higher, 21 June 2019, https://www.timeshighereducation.com/blog/climateemergency-and-new-civic-role-university

Craig, J. (2016) Secret Of Corbyn's 'Geography Teacher Stare', Sky News, January 7th, https://news.sky.com/story/secret-of-corbyns-geography-teacher-stare-10333565

Dorling, D. (2018) Peak Inequality: Britain's Ticking Time-Bomb, Bristol: Policy Press, p.213. 
Dorling, D. (2020) Slowdown: The End of the Great Acceleration-and Why it's Good for the Planet, the Economy, and Our Lives, New Haven: Yale University Press (forthcoming).

Dorling, D., Smith, G., Noble, M., Wright, G., Burrows, R., Bradshaw, J., Joshi, H., Pattie, C., Mitchell, R., Green, A. E., McCulloch, A. (2001) How much does place matter? Environment and Planning A, Volume 33, No. 8., 1335-1369

Esson, J., Noxolo, P., Baxter, R., Daley, P. and Byron, M. (2017) The 2017 RGS-IBG chair's theme: decolonising geographical knowledges, or reproducing coloniality? Commentary, Area, 2017, 49.3, 384-388, doi: 10.1111/area.12371

Frank, R. H. (2016) Success and Luck: Good Fortune and the Myth of Meritocracy, Princeton. Harrowell, E., Davies, T. and Disney, T., 2018. Making space for failure in geographic research. The Professional Geographer, 70(2), pp.230-238.

Jarvis, J. (2019) “Greta Thunberg Speech: Activist Tells Extinction Rebellion London Protesters 'We Will Make People in Power Act on Climate Change,'” London Evening Standard, 22 April, https://www.standard.co.uk/news/london/greta-thunberg-tellsextinction-rebellion-protesters-we-will-make-people-in-power-act-on-climatea4122926.html.

Legg, S. (2017) Decolonialism, Transactions of the Institute of British Geographers, Volume 42, Issue3, September, Pages 345-348

Noxolo, P. (2017) Introduction: Decolonising geographical knowledge in a colonised and recolonising postcolonial world, , 49.3, 317-319, doi: 10.1111/area.12370

O'Grady, N. (2018) Geographies of Affect, Oxford Bibliographies, 22 February, http://www.oxfordbibliographies.com/view/document/obo-9780199874002/obo9780199874002-0186.xml

Price, M. D. (2001) The Kindness of Strangers, Geographical Review, Vol. 91, No. 1/2, Doing Fieldwork (Jan. - April), pp. 143-150.

Selle, A. (2017) Presidents Corner, Blog of the Women's federation for world peace USA: living by the logic of love, 14 August, https://www.wfwp.us/presidents-corner/president-scorner-august-17

The Times (1899) The Oxford School of Geography, March 29th , page 4, Issue 35789. (895 words).

University of Liverpool (2017) Centenary of Geography and Geology celebrated, University web page published on 26 September, https://www.liverpool.ac.uk/earth-ocean-andecological-sciences/news/articles/university-celebrates-centenary-of-geography-andgeology 
University of Liverpool (2019) The perfect place to study Geography, University webpages accessed May $27^{\text {th }}$ : https://www.liverpool.ac.uk/geography-and-planning/geographyprogrammes/geography-at-liverpool/

Walker, P. (2019) Leader of Nigel Farage's party resigns over anti-Islam messages: Catherine Blaiklock sent racist posts and retweeted those of far-right figures before joining Brexit party, The Guardian, 20 March, https://www.theguardian.com/world/2019/mar/20/leaderof-pro-brexit-party-catherine-blaiklock-resigns-over-anti-islam-messages

Wayne, J. (1949) Never Apologize, clip: https://www.youtube.com/watch?v=0hY4iqMfGU4

\title{
Endnotes:
}

\begin{abstract}
${ }^{1}$ The 2017 event included a three-course black tie dinner priced at $f 60$ a head in St George's Hall Liverpool. The hall is associated with funding from former slave trader families, although it was built after the formal abolition of that trade, aided by the British government's full compensation of the slavers. Details can be found here: https://web.archive.org/web/20180122004221/https://alumni.liv.ac.uk/events/a-tale-of-two-centenaries
\end{abstract}

${ }^{2}$ For readers from abroad who do not yet know, and also those from England who have not been forced to learn this yet, in England - where up is down and down is up and people drive on the left and dress to the right - public school means extremely elite, private, very expensive, often boarding away from their parents, school.

${ }^{3}$ Here I am referring to the current Research Assessment Framework of the UK. If you are reading this outside of the UK; or even in the UK in a few years' time this will hopefully mean nothing to you - for which I apologize. As I write, tens of thousands of British academics are wasting hours of their precious (single only-once-ever-tobe-lived) lives agonizing on the number of stars to award to each other's work as they try to present the best side of their collective selves like some teenager daubing on makeup and asking his or her friends, or worse strangers, on Snapchat, Instagram, or Facebook, if they look good in this. Incidentally, a friend who commented on this piece as it was being written and rewritten suggested that when it comes to $4^{*}$ work, then for her the constellation Pegasus square springs up in her mind, a fairly innocuous little four-star constellation. In Britain $4^{*}$ is said to be work of practically intergalactic importance. It would be funny if it did not cause so much upset.

${ }^{4}$ The word count grew too long and so it became an article which was then carefully refereed (interventions are less policed). In particular, I am very grateful to the editor, Kate Swanson, for the time and trouble she took over the final text, to the two anonymous referees and to my many friends and colleagues who kindly looked over earlier drafts; as well as to Thom Davies who originally emailed me in October 2018 and suggested that I write for this special issue that Tom Disney, Elly Harrowell and he were putting together. Their comments were also very useful and kind and careful.

${ }^{5}$ As my colleague at Oxford, Rich Grenyer, explained in a tweet published on 6 October 2019: 'A-levels are no longer accurate metrics of the thinking and working skills I need to see in students. They haven't been for years. Outside the syllabus, $4 A^{*}$ students can struggle. More freedom to diversify offers isn't just an ethical imperative, but profoundly selfish too.' By which he means it is in the self-interest of a university such as Oxford not to simply admit those with the highest exam results. He was replying to a tweet by James Rolfe: 'There are myriad stories of people who don't do that well at A levels for all sorts of reasons - many linked to deprivation - who excel in later life. A level grades aren't the only determinant. The phrase "lowering standards" might equally read "finding better standards".' https://twitter.com/rich_/status/1180826412745408512?s=20 
${ }^{6}$ On interviewing for University admissions, of course many academics do try hard to do this job properly. But is it a job which should be being done at all ? They might say that by not engaging you are removing your critical view from the process and leaving it to people who have the arrogance to think they can make these decisions. Or they might say that I should engage and do a good job and use the power to even things up despite the massive obstacles. But, outside of Britain, universities are far more open to those young people who live around them. Schools do not interview prospective pupils. Why should universities do this? 